\title{
Farklı Işık Şiddetinin Bakla'da (Vicia faba L.) Verim ve Bazı Bitkisel Özelliklere Etkisi
}

\author{
M. Serhat ODABAŞ ${ }^{1}$
}

\author{
Ali GÜLÜMSER ${ }^{1}$
}

Geliş Tarihi: 29.03 .2005

\begin{abstract}
Öz: Bu çalışma, farklı ışık şiddetlerinin $\left(337.35 \mu \mathrm{molm}^{-2} \mathrm{~s}^{-1}\right.$ ve $\left.1128.39 \mu \mathrm{molm}^{-2} \mathrm{~s}^{-1}\right)$ baklada (Vicia faba L.) bitki boyu, gövde çapı, yaprak sayısı, ilk bakla yüksekliği, bakla boyu-eni-kalınlığı, bitkide bakla sayısı, taze bakla ve kuru tane verimi gibi öğeler üzerine etkisini tespit etmek amacıyla yapılmıştır. Işık şiddetinin baklada tane ve 1000-tane ağırığı hariç, incelenen karakterlere etkili olduğu görülmüştür. Düşük ve yüksek ışık şiddetlerinde sırasıyla bitki boyu 61.2 ve $50.1 \mathrm{~cm}$; gövde çapı 7.5 ve $9.9 \mathrm{~mm}$; yaprak sayısı 19 ve 25 adet; ilk bakla yüksekliği 22.2 ve $18.9 \mathrm{~cm}$; bakla boyu 9 ve $15 \mathrm{~cm}$; bakla eni 1.2 ve $2.2 \mathrm{~cm}$; bakla kalınlığı 1.4 ve $1.9 \mathrm{~cm}$; bitkide bakla sayısı 3.6 ve 6.2 adet; taze bakla verimi 403 ve $679 \mathrm{~kg} / \mathrm{da}$ ile kuru tane verimi 121 ve $211 \mathrm{~kg} / \mathrm{da}$ olarak bulunmuştur. Elde edilen araştırma sonuçlarına göre, baklanın veriminin ışık şiddetine bağlı olarak artığı belirlenmiştir.
\end{abstract}

Anahtar Kelimeler: Bakla, verim, ışık şiddeti.

\section{Effect of Different Light Intensities on Some Plant Characteristics and Yield of Faba Bean (Vicia faba L.)}

\begin{abstract}
This study was carried out to determine the effect of different light intensities $\left(337.35 \mu \mathrm{molm}^{-2} \mathrm{~s}^{-1}\right.$ and $1128.39 \mu \mathrm{molm}^{-2} \mathrm{~s}^{-1}$ ) on characteristics such as plant heigth, stem diameter, number of leaves, the height of the first pod, pod length, pod width, the thickness of pod, number of pod per plant, fresh yield and grain yield. The different light intensities effected all investigated characteristics except seeds per pod and 1000 seed weight. At low and high light intensities respectively plant heigth was 61.2 and $50.1 \mathrm{~cm}$; stem diameter 7.5 and $9.9 \mathrm{~mm}$; the number of leaves 19 and 25, the height of the first pod 22.2 and $18.9 \mathrm{~cm}$, pod length 9 and $15 \mathrm{~cm}$, pod width 1.2 and $2.2 \mathrm{~cm}$, the thickness of pod 1.4 and $1.9 \mathrm{~cm}$; the number of pod in the plant is 3.6 and 6.2; fresh yield is 4030 and $6790 \mathrm{~kg} / \mathrm{ha}$; grain yield is 1210 and $2110 \mathrm{~kg} / \mathrm{ha}$. According to obtained results, faba bean yield increased depending on light intensity.
\end{abstract}

Key Words: Faba bean, yield, light intensity.

\section{Giriş}

Insanlar tarafından kontrol edilemeyen çevre faktörleri, bir bölgede kurulacak agroekosistemlerin şekillenmesinde birinci derecede etkilidir. Bu nedenle, bir bölgede yetiştirilecek ürün çeşidinin sıcaklık, ışık yoğunluğu, gün uzunluğu ve yağış gibi etmenlerle uyumlu olması istenir. Dünyada yaşayan tüm canlıların çeşitliliğinde; güneş ışınları, sıcaklık, basınç, nem ve hava hareketleri gibi iklim faktörleri çok büyük rol oynar (Eser 1986).

Işık, bitki gelişimini etkileyen en önemli unsurlardan biridir. Bazı bitkiler tam güneş ışığı altında, bazıları ise gölgede daha iyi gelişirler. Denizin derinliklerinde veya karanlıkta yetişebilen bazı bitkiler hariç, diğer tüm bitkiler büyüme, gelişme ve üremelerini tamamlayabilmek için mutlak ışığa ihtiyaç duyarlar. Bitkiler, cins ve türlerine göre farklı ışık yoğunluklarına uyum sağlamışlardır. Işık yoğunluğu değiştiğinde bu bitkilerde büyüme, gelişme ve üreme fonksiyonları yavaşlamakta ya da hiç görülmemektedir (Kevseroğlu 1999). Bitkilerde büyüme ve gelişme için gerekli olan enerjinin kaynağı, güneş ışığından sağlanmaktadır. Güneşten yeryüzüne ulaşan güneş enerjisi, dalga boyu uzunlukları 290-5000 milimikron arasında değişen elektromanyetik dalgalardan oluşur. Bunlardan yalnızca 400-760 milimikron dalga boyuna sahip ışınlar gözle görülebilirler. Fotosentezde mavi-yeşi ışınlarda etkili olmakla beraber dalga boyları 600-760 milimikron arasında olan kırmızı ışınlar klorofil tarafından absorbe edilen ve fizyolojik aktiviteleri en yüksek olan ışınlardır. Bu ışınlar en uygun düzeyde olduğunda, bitkiler en yüksek derecede organik madde üretirler (Genç ve Tükel 1992, Maddonni ve ark. 2001, Odabaş 2003).

İnsan beslenmesinde önemli yeri olan bakla, bilhassa intiva ettiği yüksek proteinden dolayı dikkate değer bir yemeklik baklagil bitkisidir (Summerfield 1985, Duc 1997). Ülkemizin hemen her yerinde yetişebilme özelliğine sahip olmasına rağmen, baklanın üretim ve tüketimi oldukça sınırlı kalmış, bu bitkiye gereken önem verilmemiştir. Ilıman bölgelerde kışlık olarak da ekilen baklanın, uygun toprak ve hava sıcaklığında iyi bir çıkıştan sonra fide geliştirebilmesi, şüphesiz ki verim ve bitkide meyve gelişimi ile verim unsurlarını önemli derecede etkileyecektir.

Bu çalışmada, baklanın bitki ve meyve gelişimi ile verimi üzerine ışık şiddetinin etkileri tespit edilmeye çalışılmıştır.

\section{Materyal ve Yöntem}

Çalışma, Ondokuz Mayıs Üniversitesi Ziraat Fakültesine ait tarla deneme alanı ve deneme seralarında

\footnotetext{
${ }^{1}$ Ondokuz Mayıs Üniv. Ziraat Fak. Tarla Bitkileri Bölümü-Samsun
} 
3 tekrarlamalı olarak tesadüf blokları deneme desenine göre kurulmuş ve 2002-2003 yıllarında yürütülmüştür. Her iki yılda denemeler Nisan ayının son haftasında ekilmiş ve Ağustos ayının son haftasında hasat edilmiştir.

Her bloğun yarısında gölgeleme işlemi yapılmıştır. Gölgeleme materyali olarak, ı̧̧ık geçirgenliği \%50 olan koyu yeşil renkte polietilen ağlar kullanılmıştır. Bu ağlar, yerden $180 \mathrm{~cm}$ yükseklikte blokların yarısını içine alacak şekilde çakılan kazıklara gerilmiştir.

Araştırmada, May Tohumculuktan temin edilen Lara çeşidi kullanılmıştır. Sertifika numarası 185/P, safiyeti $\% 99.9$ ve çimlenme gücü $\% 88$ olan çeşidin tohumları 15 $\mathrm{cm}$ sıra üzeri ve $50 \mathrm{~cm}$ sıra arası mesafe olacak şekilde ekilmiştir.

Işık şiddeti Delta-T marka "canopy sun scan analyser" cihazı ile yapılmıştır. Alet, yerden $1 \mathrm{~m}$ yükseklikte tutularak bitkilerin gölgelemesinden etkilenmeyecek şekilde ışık ölçümleri yapılmıştır (Purcell 2000, Cemek 2002). Denemede vejetasyon periyodu süresince ortalama ışık şiddeti gölgeli ortamda 337.35 $\mu \mathrm{molm} \mathrm{s}^{-1}$, gölgesiz ortamda ise $1128.39 \mu \mathrm{molm}^{-2} \mathrm{~s}^{-1}$ olarak tespit edilmiş ve denemenin istatistiki analizinde bu iki ışık şiddeti dikkate alınmıştır.

Deneme alanı toprağının doygunluk oranı \%66, toplam tuz oranı \%0.07, $\mathrm{pH}=7$ (nötr), $\mathrm{P}_{2} \mathrm{O}_{5} 13 \mathrm{~kg} / \mathrm{da}$ (iyi), $\mathrm{K}_{2} \mathrm{O} 30 \mathrm{~kg} / \mathrm{da}$ (düşük) ve organik madde 2.93 değeri ile orta olarak tespit edilmiştir.

Çalışmanın yapıldığı yıllara ait iklim verilerinden sıcaklık, yağış ve nispi nem değerleri Çizelge 1'de verilmiştir.

Denemenin varyans analizi tesadüf blokları deneme desenine göre SAS 9.0 paket programı kullanılarak yapılmıştır. İki ışık değeri arasındaki kıyaslama ortalamaları dikkate alınarak yapılmıştır. Bitkisel özellikler ve verimle ilgili ölçümler / tartımlar aşağıda açıklandığı gibi yapılmıştır.

Bitki boyu: Her parselden şansa bağlı olarak belirlenen 10 bitkinin, toprak yüzeyinden gövde ucuna kadar olan boyları ölçülüp ortalama bitki boyu hesaplanmış ve $\mathrm{cm}$ olarak ifade edilmiştir.

Gövde çapı: Parsellerden şansa bağlı olarak belirlenen 10 bitkinin ilk bakla bağladığı boğum arası esas alınarak dijital kumpas yardımı ile gövde çapları ölçülerek ortalaması alınmış ve $\mathrm{mm}$ olarak ifade edilmiştir.

Çizelge 1. 2002-2003 yıllarında vejetasyon dönemine ait iklim verileri

\begin{tabular}{|c|c|c|c|c|c|c|c|}
\hline \multirow[b]{2}{*}{ Rasat } & \multirow[b]{2}{*}{ Yıllar } & \multicolumn{5}{|c|}{ Aylar } & \\
\hline & & 4 & 5 & 6 & 7 & 8 & \\
\hline \multirow{2}{*}{$\begin{array}{l}\text { Sic.Ort. } \\
\left({ }^{\circ} \mathrm{C}\right)\end{array}$} & 2002 & 10.2 & 15.8 & 20.8 & 25.6 & 23.6 & 19.2 \\
\hline & 2003 & 8.7 & 16.2 & 20.7 & 23.7 & 24.1 & 18.7 \\
\hline \multirow{2}{*}{$\begin{array}{l}\text { Top.Yağış } \\
\text { (mm) }\end{array}$} & 2002 & 61.9 & 10.9 & 53.8 & 77.9 & 14.3 & 218.8 \\
\hline & 2003 & 45.0 & 54.7 & 3.3 & 37.2 & 3.4 & 143.6 \\
\hline \multirow{2}{*}{$\begin{array}{l}\text { Nispi } \\
\text { Nem (\%) }\end{array}$} & 2002 & 79.8 & 74.2 & 74.4 & 73.5 & 73.3 & 75.0 \\
\hline & 2003 & 79.6 & 78.4 & 68.8 & 72.5 & 72.9 & 74.4 \\
\hline
\end{tabular}

Yaprak sayısı: Her bir parselden rasgele seçilen 10 bitkinin tam bakla bağlama döneminde toplam yaprakları sayılarak ortalama yaprak sayısı belirlenmiş ve adet olarak ifade edilmiştir.

İlk bakla yüksekliği: Kuru olgunluk devresinde şansa bağlı olarak seçilen 10 bitkide toprak seviyesinden itibaren ilk meyvenin oluştuğu yükseklik ölçülüp ortalaması alınmış ve cm olarak tanımlanmıştır.

Bakla Boyu: Gözleme alınan bitkilerden şansa bağlı olarak seçilen 10 baklanın boyları ölçülüp ortalamaları alınarak $\mathrm{cm}$ olarak ifade edilmiştir.

Bakla eni: Ölçüm yapılan bitkilerden şansa bağlı olarak seçilen 10 baklanın enleri ölçülüp ortalamaları alınarak mm olarak saptanmıştır.

Bakla kalınlığı: Üzerinde ölçüm yapılan bitkilerden şansa bağlı olarak seçilen 10 baklanın kalınlıkları ölçülüp ortalamaları alınarak mm olarak tespit edilmiştir.

Bitkide bakla sayısı: Şansa bağlı olarak seçilen 20 bitkide baklalar sayılmış ve ortalamaları adet olarak belirlenmiştir.

Taze bakla verimi: Kenar tesirler çıkarıldıktan sonra kalan bitkilerden taze bakla hasadı yapılarak parsel başına taze bakla verimi bulunmuştur. Daha sonra verim dekara kg olarak hesaplanmıştır.

Kuru tane verimi: Tam olgunluk dönemine gelen bitkilerden kuru baklalar elle hasat edilmiştir. Daha sonra kabuklarından ayrılan baklalardaki daneler tartılarak parsele kuru tane verimi tespit edilmiş ve bu verilerden dekara $\mathrm{kg}$ olarak tane verimi hesaplanmıştır.

\section{Bulgular ve Tartışma}

Araştırmada ele alınan verim ve bitkisel özelliklere ait ortalama değerler aşağıdaki çizelgede gösterilmiştir (Çizelge 2).

Bitki boyu: Yapılan varyans analiz sonucu ışık şiddetinin bitki boyuna etkisi önemli $(\mathrm{P}<0.05)$ bulunmuştur.

Çizelge 2. Verim ve bitkisel özelliklere ait değerlerin ortalamaları

\begin{tabular}{|c|c|c|}
\hline \multirow{2}{*}{ Özellikler } & \multicolumn{2}{|c|}{ Işık şiddetleri $\left(\mu \mathrm{molm}^{-2} \mathrm{~s}^{-1}\right)$} \\
\hline & 337.35 & 1128.39 \\
\hline Bitki boyu (cm) & $61.2^{*}$ & 50.1 \\
\hline Gövde çapı (mm) & $7.5^{*}$ & 9.9 \\
\hline Yaprak sayısı (adet) & $19.0^{*}$ & 25.0 \\
\hline İlk Bakla yük. (cm) & $22.2^{*}$ & 18.9 \\
\hline Bakla boyu (cm) & 9.0 ** & 15.0 \\
\hline Bakla eni $(\mathrm{cm})$ & $1.2^{* *}$ & 2.2 \\
\hline Bakla kalınlığı (cm) & $1.4^{* *}$ & 1.9 \\
\hline Bit. bakla (adet) & $3.6^{*}$ & 6.2 \\
\hline Bak. tane (adet) & 4.0 & 4.0 \\
\hline 1000-tane ağır. (g) & 630.0 & 637.3 \\
\hline Taze verim (kg/da) & 403.0 & $679.0^{*}$ \\
\hline Kuru tane V. (kg/da) & 121.0 & 211.0 * \\
\hline
\end{tabular}


Işık şiddetinin fazla oluşu bitkilerde boyun kısalmasına neden olmuştur. Düşük ışık şiddetinde $\left(337.35 \mu \mathrm{molm}^{-2} \mathrm{~s}^{-1}\right)$ ortalama $61.2 \mathrm{~cm}$ olan bitki boyu, yüksek ışık şiddetinde (1128.39 $\mathrm{mmolm}^{-2} \mathrm{~s}^{-1}$ ) $50.1 \mathrm{~cm}$ 'de kalmıştır (Şekil 1). Loş ışık altında çimlendirilen ve büyümeye terk edilen bitkilerde ince, uzun ve gevrek yapıda hızlı bir büyüme gözlenmektedir. Bitki güneş ışığına çıkarılınca gövdede pigmentler artmakta, gövde kalınlaşmakta ve gövde uzaması nispeten yavaşlamaktadır. Yüksek ışık altındaki bitkilerde görülen kısa kalma durumu bu çalışmada da kendini göstermiştir. Bitkiye gelen ışık, yoğunluğu ve süresine göre bitki organlarının yapıları ve çalışmaları üzerinde büyük oranda etkilidir. Işık şiddetinin fazla olması bitki boyu ve boğum aralarının kısalmasına neden olmaktadır (Eser 1986). Yapılan bu çalışmada bitki boyu, gövde çapı ve ilk bakla yüksekliği ışık şiddetinden önemli düzeyde etkilenmiştir. $1128.39 \mu \mathrm{molm}^{-2} \mathrm{~s}^{-1}$ Işık şiddetinde bitki boyu $337.35 \mu \mathrm{molm}^{-2} \mathrm{~s}^{-1}$ Işık şiddetine göre daha kısa olmasından dolayı ilk bakla yüksekliği de buna bağlı olarak daha kısa kalmıştır. Yüksek Işık şiddetine maruz kalan bitkilerde boy kısalığının yanında gövde kalınlığı da artmıştır. Kevseroğlu (1999), bol ışığın bitki boyunu ve boğum aralarını kısalttığını ve sap sağlamlığını artırdığını bildirmektedir.

Gövde çapı: Varyans analiz sonucu ışık şiddetinin gövde çapına etkisi önemli $(P<0.05)$ bulunmuştur. Artan ışık şiddetinde bitkilerin gövdelerinde bariz bir kalınlaşma gözlemlenmiştir.

Nitekim, $337.35 \mu \mathrm{molm}{ }^{-2} \mathrm{~s}^{-1}$ Işık şiddetinde gövde çapı ortalaması $7.5 \mathrm{~mm}$ iken, $1128.39 \mu \mathrm{molm}^{-2} \mathrm{~s}^{-1}$ ışık şiddetinde $9.9 \mathrm{~mm}$ olmuştur (Şekil 2). Işık şiddetinin azlığı bitki boyunun uzamasına neden olurken, gövdenin cılız ve hatta sülüksü bir durum almasına neden olur. Işığın yoğunluğu ile beraber gövde kalınlaşır ve dayanıklı bir yapıya kavuşur. Burada da benzer bir durum söz konusudur. Bol ışık, bitkilerin saplarını sağlamlaştırmakta ve kalınlaştırmaktadır (Kevseroğlu 1999).

Yaprak sayısı: Varyans analiz sonucu, ışık şiddetinin bitkide yaprak sayısına etkisi önemli $(P<0.05)$ bulunmuştur. Şiddetli ışık altında kalan bitkilerde toplam yaprak sayısı adet olarak artmıştır. Işık yoğunluğunun azalmasına paralel olarak bitki başına yaprak sayısı da azalmıştır. Bu durum Şekil 3'te görüleceği gibi 337.35 $\mu \mathrm{molm}{ }^{-2} \mathrm{~s}^{-1}$ ışık şiddetinde yaprak sayısı ortalaması 19

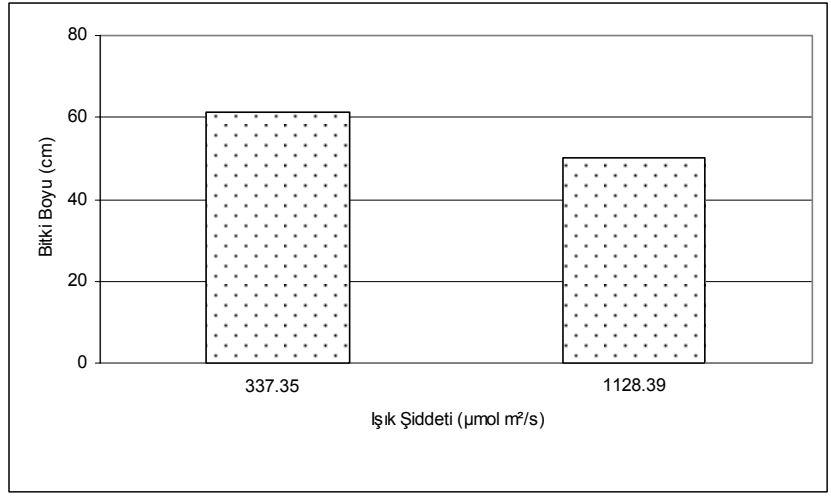

Şekil 1. Baklada farklı ışık şiddetlerinde bitki boyunun değişimi

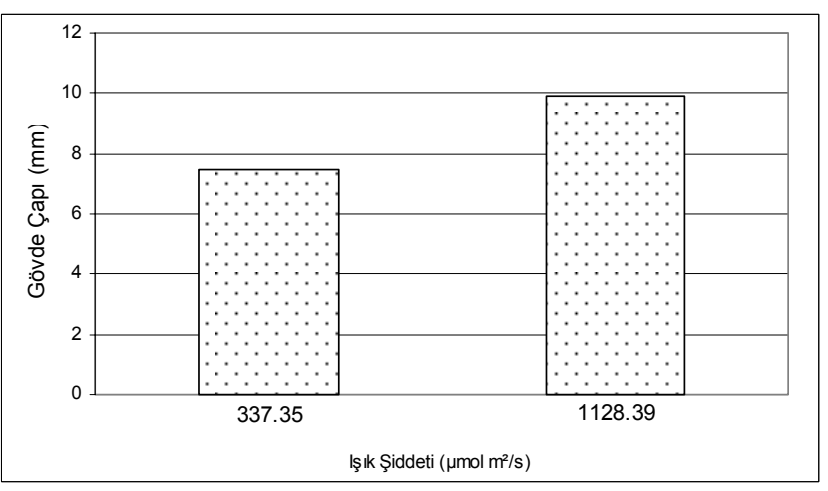

Şekil 2. Baklada farklı ışık şiddetlerinde gövde çapının değişimi

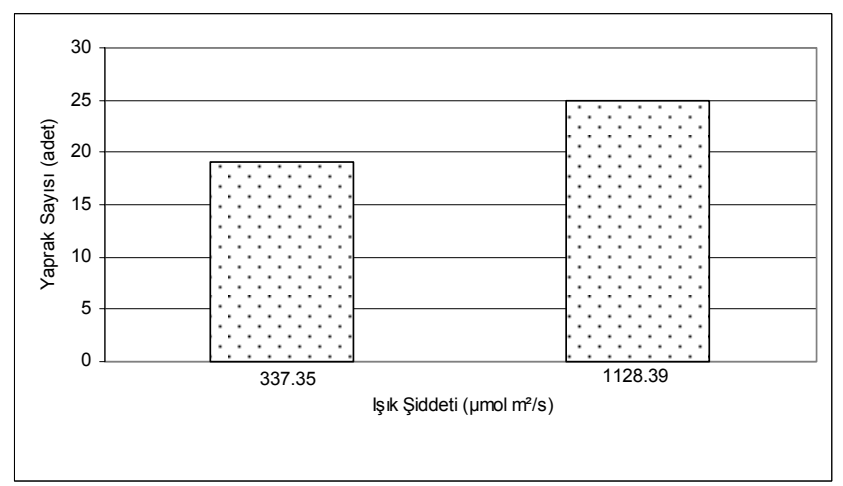

Şekil 3. Baklada farklı ışık şiddetlerinde yaprak sayısının değişimi

adet olurken, $1128.39 \mu \mathrm{molm}^{-2} \mathrm{~s}^{-1}$ Işık şiddetinde 25 adet olmuştur.

Işıklanmanın yetersiz veya az olduğu durumlarda yapraklar yüzeysel olarak geniş, ince ve nazik bir yapıda olurlar. Ancak, ışığın artması ve fazlalığı yaprakların çok sayıda ama küçük ve kalın yapıda olması sonucunu doğurur. Işık, bitkilerde gövde, dal, yaprak ve meyve dokularının daha sert ve dayanıklı olmasına neden olur. Uzun ve Demir (1996), yaprak çıkış oranının sıcaklık artışı ile doğru orantılı olarak arttığını bildirmektedirler. Ayrıca, Warrington ve Kanemasu (1983), mısırda (Zea mays L.) yaprak çıkış oranının $15-28^{\circ} \mathrm{C}$ 'ler arasında sıcaklıkla doğru orantılı olarak arttığını belirtmektedirler.

Buğday üzerine yapılan bir çalışmada da en fazla yaprak sayısı 14 saat gün uzunluğu ve 33750 lüks ışık şiddeti uygulamasında elde edilmiştir (Ekmekçi ve Terzioğlu 1998). Bu çalışmada da benzer sonuçlar görülmektedir. Yüksek ışık, bitkilerde yaprakları sayıca artırmıştır. Işık şiddeti yaprağın şeklini, kalınlığını ve sayısını etkilemektedir. Yüksek ışık şiddetine maruz kalan bitkilerin yapraklarında stomalar küçük ve birbirine yakın olur ve epidermisleri kalındır. Buna karşılık düşük ışık şiddetinde ise yapraklar daha ince bir epidermise sahiptirler. Fazla ışığa maruz kalan bitkilerin yaprakların birbirlerine yakın olmaları bitkideki yaprak sayısının da fazla olmasına neden olmaktadır (Çepel 1988, Öztürk ve Seçmen 1992). 
İlk bakla yüksekliği: Işık şiddetinin ilk bakla yüksekliğine etkisi, yapılan varyans analiz sonucu önemli $(P<0.05)$ bulunmuştur. Yoğun ışık altında bitkilerde ilk bakla yüksekliği kısa kalırken, ışık yoğunluğunun azalması karşısında ilk baklalar daha yüksekte oluşmuştur. Örneğin, $337.35 \mu \mathrm{molm}^{-2} \mathrm{~s}^{-1}$ ışık şiddetinde ilk bakla yüksekliği ortalaması $22.2 \mathrm{~cm}$ iken, $1128.39 \mu_{\mathrm{molm}}^{-2} \mathrm{~s}^{-1}$ ışık şiddetinde $18.9 \mathrm{~cm}$ olmuştur (Şekil4).

Işık ve sıcaklığın fazlalığı bitkilerde erken generatif olgunluğu teşvik eder. Bitki boyunun kısa olması, buna bağlı olarak boğum aralarının kısa kalmasına neden olmuştur. Hem boğum aralarının kısa oluşu ve hem de ısı ve ışığın fazlalığı generatif olgunluğu teşvik etmiştir. Dolayısıyla erken çiçek açan bitkilerde ilk bakla yüksekliği düşük kalmıştır. Işık şiddetinin fazla olması bitki boyu ve boğum arasını kısaltmaktadır (Eser 1986). Burada da benzer sonuçlar ortaya çıkmıştır.

Bakla boyu: Bakla boyuna ışık şiddetinin etkis yapılan varyans analiz sonucu çok önemli $(P<0.01)$ bulunmuştur. Işık şiddetinin artması, generatif bir organ olan bitkideki baklanın (meyvenin) boyunu artırırken, düşük yoğunluktaki ışık, meyve boyunun kısa kalmasına neden olmuştur. Nitekim, $337.35 \mu \mathrm{molm}^{-2} \mathrm{~s}^{-1}$ Işık şiddetinde bakla boyu ortalaması $9 \mathrm{~cm}$ iken, $1128.39 \mu \mathrm{molm}^{-2} \mathrm{~s}^{-1}$ ışık şiddetinde $15 \mathrm{~cm}$ olarak tespit edilmiştir (Şekil 5). Işığın generatif organlar üzerine olumlu etkisi bilinmektedir. Baklada da meyvelerin yüksek ışık şiddeti altında iyi gelişmesi düşük ışık şiddeti altında yetiştirilenden daha uzun olmasına neden olmuştur. Aynı durum baklanın eni ve kalınlığı için de geçerlidir.

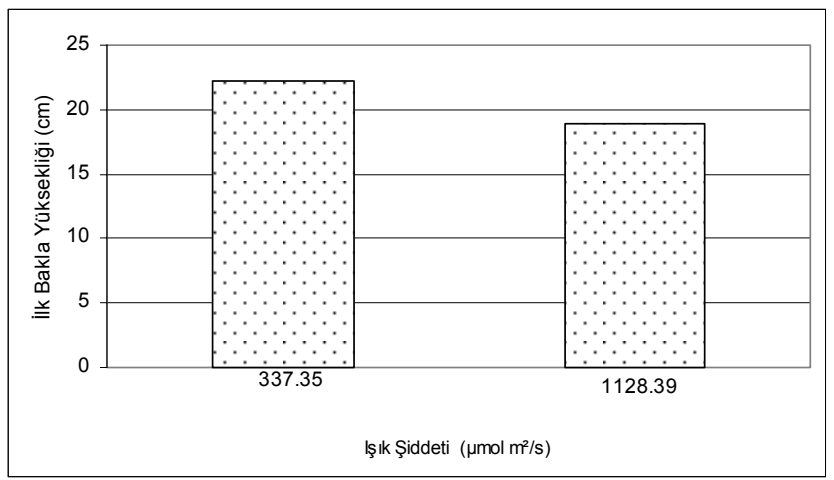

Şekil 4. Baklada farklı ışı şiddetlerinde ilk bakla yüksekliğinin değişimi

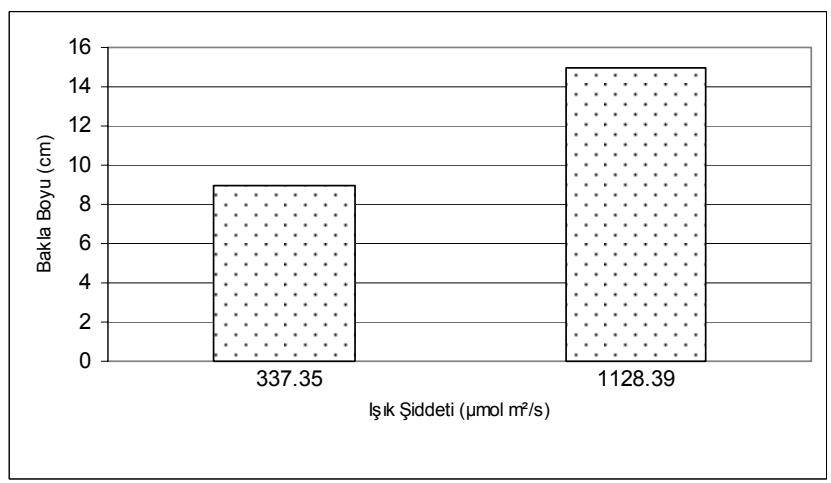

Şekil 5. Baklada farklı ışı şiddetlerinde bakla boyunun değişimi
Bakla eni: Varyans analiz sonucu ışık şiddetinin bakla enine etkisi çok önemli $(P<0.01)$ bulunmuştur. Bitkideki baklanın sayı ve uzunluğundaki artış gibi, meyvenin eni üzerine artan ışık şiddetinin olumlu etkisi olmuştur. Buna göre; $337.35 \mu \mathrm{molm}^{-2} \mathrm{~s}^{-1}$ Işık şiddetinde bakla eni ortalaması $1.2 \mathrm{~cm}$ iken, $1128.39 \mu \mathrm{molm}^{-2} \mathrm{~s}^{-1}$ Işık şiddetinde $2.2 \mathrm{~cm}$ olmuştur (Şekil6).

Işığın bakla boyuna yaptığı etki bakla eninde de benzer şekilde olmuştur.

Bakla kalınlığı: Işık şiddetinin bakla kalınlığına etkisi yapılan varyans analiz sonucu çok önemli $(P<0.01)$ bulunmuştur. Artan ışık şiddeti bitkideki baklaların sayısı, uzunluğu, eni ve boyunu olumlu yönde etkilemiştir. Şekil 7'de görüldüğü gibi $337.35 \mu \mathrm{molm}^{-2} \mathrm{~s}^{-1}$ ışık şiddetinde bakla kalınlığı ortalaması $1.4 \mathrm{~cm}$ olarak gerçekleşirken, $1128.39 \mu \mathrm{molm}^{-2} \mathrm{~s}^{-1}$ Işık şiddetinde $1.9 \mathrm{~cm}$ olmuştur.

Işık şiddeti, bakla boyu ve eninde olduğu gibi, bakla kalınlığını da benzer şekilde etkilemiştir. En fazla bakla boyu, bakla eni ve bakla kalınlığı $1128.39 \mu_{\mathrm{molm}}^{-2} \mathrm{~s}^{-1}$ ışık şiddetinden elde edilmiştir. Yeterli düzeyde ışık alan bitkilerde çiçeklenme ve meyve gücü yüksek olmaktadır (Tükel 1997). Buda baklanın eni, boyu ve kalınlığının düşük ışık şiddetine göre yüksek ışık şiddetinde daha fazla olmasını açıklamaktadır.

Bitkide bakla sayısı: Işık şiddetinin bitkide bakla sayısına etkisi yapılan varyans analiz sonucu önemli

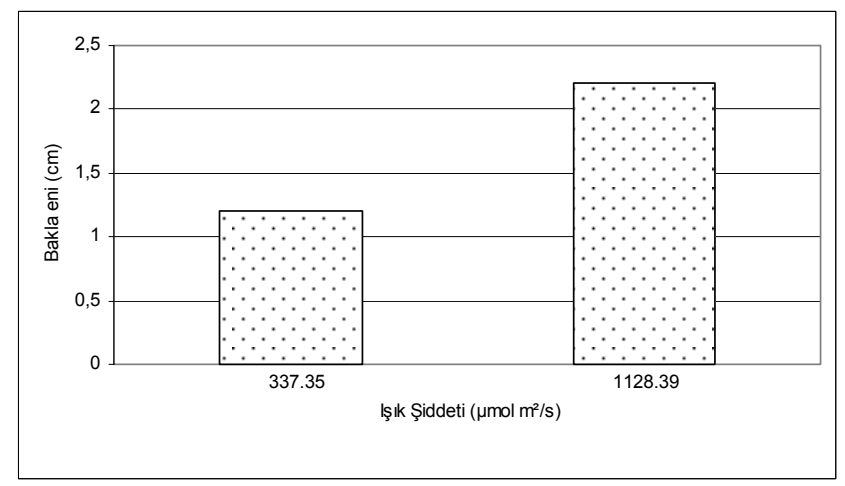

Şekil 6. Baklada farklı ısık şiddetlerinde bakla eninin değişimi

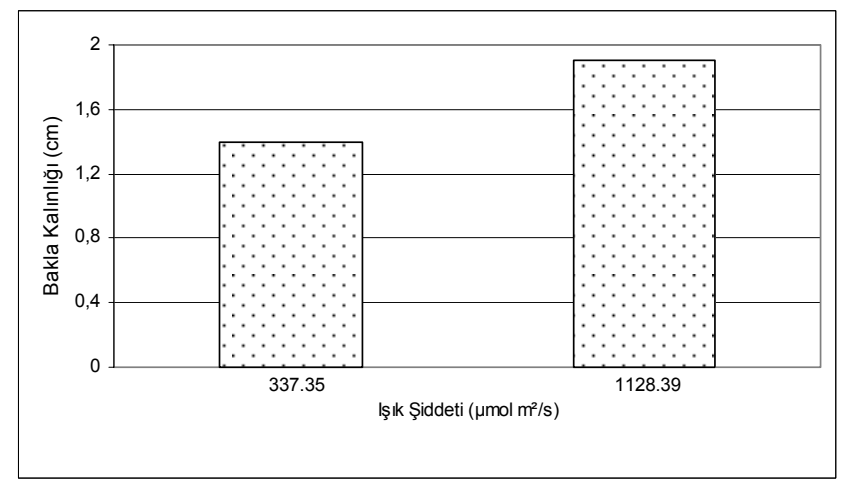

Şekil 7. Baklada farklı ışı şiddetlerinde bakla kalınlığının değişimi 
$(P<0.05)$ bulunmuştur. Bitki başına bakla sayısı ışık şiddetinin yükselmesiyle birlikte önemli derecede artmıştır. Düşük ışık şiddetinde (337.35 $\left.\mu \mathrm{molm}^{-2} \mathrm{~s}^{-1}\right)$ bitkide bakla sayısı ortalaması 3.6 adet olurken, yüksek ışık şiddetinde $\left(1128.39 \mathrm{umolm}^{-2} \mathrm{~s}^{-1}\right.$ ) 6.2 adet olmuştur (Şekil 8).

Bitkide bakla sayısı da ışık şiddetinin yeterli olduğu durumlarda artış göstermektedir. Buda yeterli ışık şiddetinin bitkide çiçeklenmeyi teşvik etmesi ve uygun şartlarda da çiçek gelişimine ve dolayısıyla bakla bağlamaya olumlu etki etmesiyle açıklanmaktadır (Aksoy, 1982). Bitkide bakla sayısı baklagillerde verim öğelerinin başında gelmektedir (Vega ve ark. 2001). Bitkide bakla sayısı, ışık şiddetine paralel olarak artmıştır. Işık yoğunluğu, önemli bir verim unsuru olan baklada tane sayısını olumlu etkilemektedir.

Taze bakla verimi: Yapılan varyans analiz sonucu ışık şiddetinin taze bakla verimine etkisi önemli $(P<0.05)$ bulunmuştur. Nitekim, $337.35 \mu_{\mathrm{molm}}^{-2} \mathrm{~s}^{-1}$ Işık şiddetinde taze bakla verim ortalaması $403 \mathrm{~kg} / \mathrm{da}$ iken, 1128.39 $\mu$ molm $\mathrm{s}^{-1}$ Işık şiddetinde $679 \mathrm{~kg} / \mathrm{da}$ olmuştur (Şekil 9).

Generatif organlardan olan bakla (meyve), yüksek ışıkta, düşük ışığa göre daha fazla olmaktadır. Sayısal artış yanında meyve kabuğu ve eti ile taze tanelerin dolgun olması da uygun ışık ve sıcaklık altında verimi olumlu yönde etkilemektedir.

Kuru tane verimi: Yapılan varyans analiz sonucu ışık şiddetinin kuru tane verimine etkisi önemli $(P<0.05)$

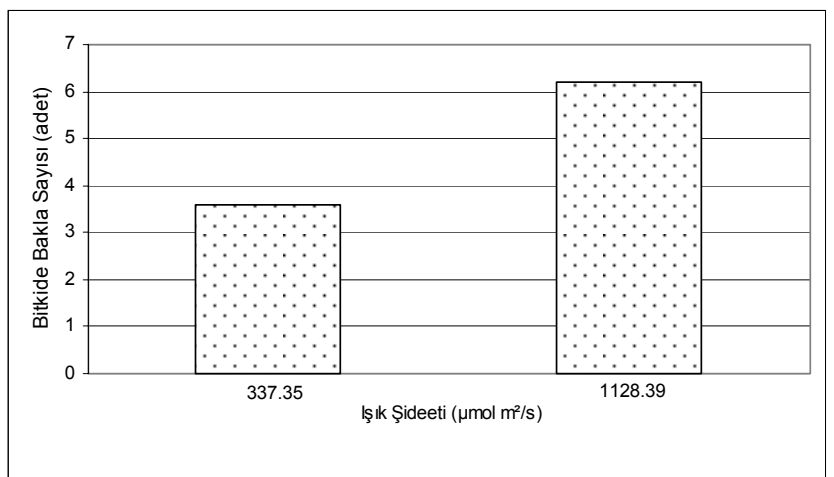

Şekil 8. Baklada farklı ışık şiddetlerinde bitkide bakla sayısının değişimi

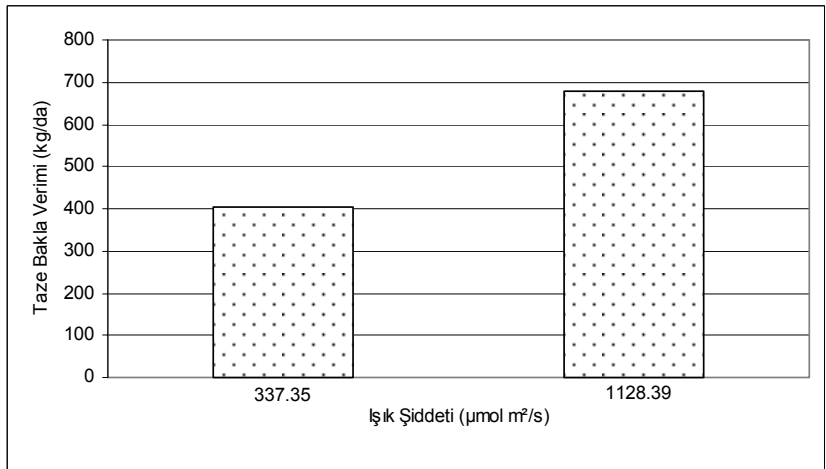

Şekil 9. Baklada farklı ışık şiddetlerinde taze bakla veriminin değişimi bulunmuştur. Düşük ışık şiddeti altında yetiştirilen baklalara göre yüksek ışık şiddetinde yetiştirilen baklanın kuru tane verimi daha fazla olmuştur. Bu durum Şekil 10'da gösterildiği gibi $337.35 \mu \mathrm{molm}^{-2} \mathrm{~s}^{-1}$ Işık şiddetinde kuru tane verim ortalaması $121 \mathrm{~kg} / \mathrm{da}$ olurken, 1128.39 $\mu \mathrm{molm} \mathrm{s}^{-2} \mathrm{~s}^{-1}$ ş̧ı şiddetinde $211 \mathrm{~kg} / \mathrm{da}$ olmuştur.

Işık şiddetinin verimi olumlu yönde artırıcı etkisini taze ve kuru tane veriminde de görmekteyiz. 1128.39 $\mu \mathrm{molm}{ }^{-2} \mathrm{~s}^{-1}$ Işık şiddetinde $337.35 \mu \mathrm{molm}^{-2} \mathrm{~s}^{-1}$ Işık şiddetine göre daha fazla verim elde edilmiştir. Işığın bitki fizyolojisi açısında olumlu katkılarından biriside yüksek verim sağlamasıdır (Öztürk ve Seçmen 1992). Bakla (meyve) veriminde olduğu gibi kuru tane verimi yüksek ışık şiddeti altında daha fazla olmuştur. Işığın fazlalığı bitkide tane ve tanenin oluşturduğu organların iyi gelişmesine ve verimin yüksek olmasına neden olmaktadır.

\section{Sonuç}

Yüksek şiddetteki ışığın baklada verim ve bitki gelişmesine etkisi, bitki boyu ve ilk bakla yüksekliği hariç, gövde çapı, yaprak sayısı, bakla boyu, bakla eni, bakla kalınlığı ile bitkide bakla sayısı, bakla ve tane verimi üzerine olumlu yönde olmuştur. Genel olarak ışık yoğunluğunun artması, bitkilerde boyun kısalmasına ve erken çiçeklenmeye neden olmaktadır. Bu çalışmada da ışık şiddetine bağlı olarak bitki boyu kısalmıştır. Önemli bir bitki özelliği olan, ilk bakla yüksekliğinin de düşük çıkması aynı nedene bağlanabilir. Burada ilk bakla bağlayan boğum sayısı her iki ışık şiddetinde de hemen hemen aynı düzeyde olurken boğum aralarının yüksek ışık şiddetinde kısa kalması bu farkın çıkmasına neden olmuştur.

Işığın bitkilerde generatif organların erken gelişmesine ve uygun ortamlarda da meyve ve tanelerde besin elementlerinin depolanmasına sebep olduğu bilinmektedir. Bu çalışmada da görülmüştür ki, yüksek ışık şiddeti altında yetiştirilen baklalarda tane verimi daha yüksek olmuştur.

Yetiştirme şartlarının uygun olduğu durumlarda güneşlenmenin fazlalığı, baklada tane verimi ile verime etkili bitkisel gelişmeye olumlu yönde etki yapmaktadır.

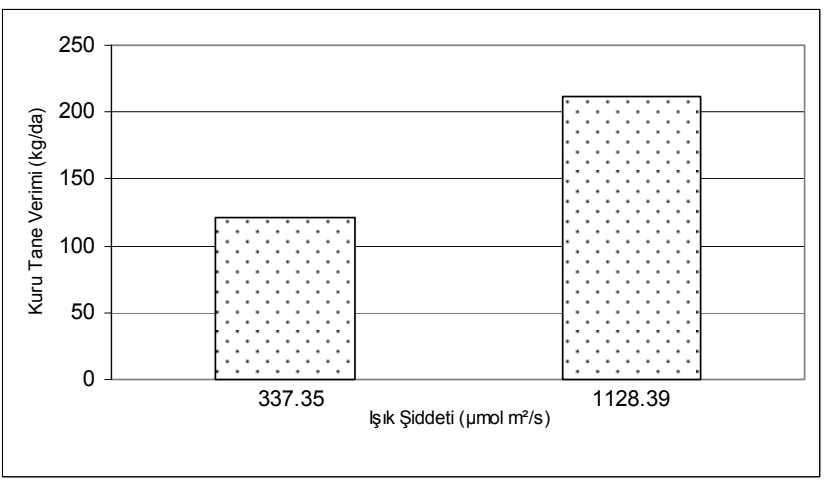

Şekil 10. Baklada farkı ışık şiddetlerinde kuru tane veriminin değişimi 


\section{Kaynaklar}

Aksoy, A. Ş. 1982. Tarımsal Ekoloji. Ege Üniv. Ziraat Fak. Teksir No:29.

Anonim 2004. Samsun Meteoroloji Bölge Müdürlüğü. Samsun.

Cemek, B. 2002. Farklı sera örtü malzemelerinin bitki büyüme, gelişme, verim ve sera içi çevre koşullarına etkisi. Ondokuz Mayıs Üniv. Fen Bilimleri Enstitüsü. (Basılmamış Doktora Tezi).

Çepel, N. 1988. Orman Ekolojisi. İstanbul Üniv. Orman Fak. Yayınları. No:399.

Duc, G. 1997. Faba bean (Vicia faba L.). Field Crops Research 53: $99-109$

Ekmekçi, Y., S. Terzioğlu. 1998. Interactive effects of vernalization, day length and light intensity on the number of leaves and flag leaf area in some wheat cultivars. Tr. J. of Botany. 22: 303-312.

Eser, D. 1986. Tarımsal Ekoloji. Ankara Üniv. Ziraat Fak. Yayınları: 975. Ders Kitabı:287. Ankara

Genç, İ., T. Tükel. 1992. Tarımsal Ekoloji. Çukurova Üniv. Ziraat Fak. Ders Kitabı. No:29 Adana.

Kevseroğlu, K. 1999. Bitki Ekolojisi. Ondokuz Mayıs Üniv. Ziraat Fak. Ders Kitabı. No: 31 Samsun.

Maddonni, G. A., M. Chelle, J. L. Drouet and B. Andriue. 2001. Light interception of contrasting azimuth canopies under square and rectangular plant spatial distributions: simulations and crop measurement. Field Crops Research 70:1-13.
Odabaş, M. S. (2003). Sıcaklık ve ışığın baklada (Vicia Faba L.) büyüme, gelişme ve verime kantitatif etkileri. Ondokuz Mayıs Üniv. Fen Bilimleri Enstitüsü. (Basılmamış doktora tezi).

Öztürk, M. A. ve Ö. Seçmen. 1992. Bitki Ekolojisi. Ege Üniv. Fen Fak. Yayın No:141.

Purcell, L. C. 2000. Soybean canopy coverage and light interception measurements using digital imagery. Crop. Sci. 40: 834-837.

Uzun, S. ve Y. Demir. 1996. Sıcaklık ve ışığın bitki büyüme, gelişme ve verimine etkisi. (II. Gelişme). Ondokuz Mayıs Üniv. Ziraat Fak. Dergisi 11 (3): 201-212.

Summerfield, R. J. 1985. Grain Legumes Crops. Collins Professional and Technical Books.

Tükel, T. 1997. Tarla Bitkileri Ekolojisi (I. Bölüm). Çukurova Üniv. Ziraat Fak. Ders Kitapları Yayın No:54.

Vega, C. R. C., F. H. Andrade and V. O. Sadras. 2001. Reproductive partitioning and seed set efficiency in soybean, sunflower, maize. Field Crops Research. 163-175.

Warrington, I. J. and E. T. Kanemasu. 1983. Corn growth response to temperature and photoperiod I. Seedling Emergence, Tassel İnitiation and Anthesis. Agronomy J. 75: 749-754.

İletişim adresi:

M. Serhat ODABAŞ

Ondokuz Mayıs Üniv. Ziraat Fak. Tarla Bitkileri Bölümü-Samsun 